Conference

\title{
ACRL imagines libraries of the future
}

\section{Highlights of ACRL programs at ALA's 1997Annual Conference}

ACRL members enjoyed cool, sunny days in San Francisco during ALA's 116th Annual Conference June 26-July 3. Total conference attendance was approximately 23,201 members, exhibitors, and guests, including 12,059 paid registrants. Many of ACRL's sections sponsored this year's President's Program, which was given to a standing room only crowd of more than 1,000. (Ed note: Thanks to the many members who summarized programs for CERL News so that we could bring you this report.)

\section{Imagining the learning library}

The ACRL President's Program [cosponsored by the following six sections of ACRL: Instruction; College Libraries; Community and Junior College Libraries; Education and Behavioral Sciences; Extended Campus Library Services; and Asian, African, and Middle Eastern] explored the vision of the "learning library," which would invite exploration and present opportunities for learning and research. Maureen Sullivan Lan organizational development consultantl moderated the session, which featured Betsy Baker from Northwestern University, Peggy Van Pelt and Barry Braverman from Walt Disney Imagineering, and Craig Hartman from Skidmore, Owings \& Merrill.

In the context of conflicting views of the library's mission, Baker suggested that we need a clear and unifying "story" to provide meaning and purpose and bring order out of chaos. She proposed the consideration of four core values that would shape the library's story: 1) convergence, or bringing together various resources and points of view, 2) conduciveness, or leading people to resources, 3) conveyance, carrying a recognizable library identity to the public, and
4) community, integrating the library into the university's learning community.

Van Pelt and Braverman found similarities between their work as Disney theme park designers and the challenge that librarians face in designing the learning library. Van Pelt discussed the importance of cooperation, teamwork, communication, storytelling (marketing ideas), community, and imagination which are vital elements in converting ideas into reality. Most important, librarians must know their audience, the learners.

Braverman argued that the library must first identify its mission before making any changes. Then it will be in a position to identify its competitors and develop programs that only it can provide. Braverman cautioned that libraries must reach a balance between implementing new technologies and maintaining traditional services that patrons want.

Hartman brought an architect's perspective to the design of the learning library, arguing that the architectural design of libraries must accommodate the disparate demands of technology, environment, and the communities of users.Jim Terry, New York University (Reprinted with

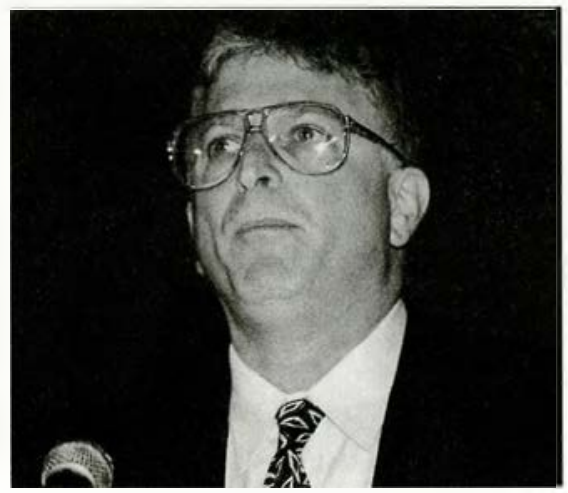

Braverman argued that the library must first identify its mission before making any changes. 
permission from Cognotes, Conference Wrapup, July 1997)

Ed. note: Following the program an exciting Showcase of Ideas featured some of the innovative ways that academic librarians are communicating the library's educational mission and creating learning environments in their institutions. Among the nineteen presentations was Leigh Carruthers and Valeda Dent's display regarding the University of Michigan's Interactive Reference Assistant (IRA) project, which allows residence hall libraries to access reference services at the undergraduate library using desktop conferencing. Other highlights included Nancy O'Hanlon's presentation of Ohio State University's net. Tutor, a web-based tutorial offering self-paced interactive lessons on using the Internet for scholarly research, and University of North Texas librarians Monika Antonelli, Jeff Kempe, and Greg Sidberry's lively demonstration of how to integrate creative theatrical touches into library instruction classes.

\section{African Americans in San Francisco}

Did you know the first jazz club anywhere is still standing-in Sán Francisco??

On Saturday, June 28 , in association with the ACRL's African-American Studies Librarians Section and the Black Caucus of ALA, there was a gathering of griots (an African expression for oral storyteller) to show and tell about the African American experience in San Francisco as well as honor Charlemae Hill Rollins, the first black librarian to be given honorary life membership

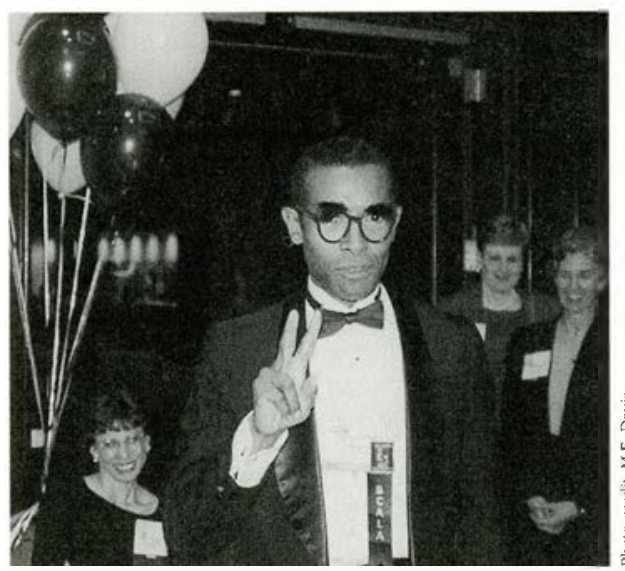

Greg Sidberry demonstrates theatrical presentation techniques during the "Showcase of Ideas" following the ACRL President's Program. by the ALA, and be elected president of the Children's Services Division of ALA.

A bus toured the city of San Francisco, stopping to point out significant landmarks of the founding contributions of blacks to California, which have been ignored or buried in today's mainstream resources. Did you know that California was named after a treasure island in the popular Spanish tale "Las Serges des Esplendien," written by Spanish author Garcia Ordonez Montavlvo in 1510 ? But, did you know that the mystical island was inhabited by black women and ruled by Queen Calafia? John William Templeton directed the tour and is also co-editor of Our Roots Run Deep: The Black Experience in California, a resource that will answer all these questions and more. He gave oral highlights on Leidesdorff Street, named for William Alexander Leidesdorff (1810-1848), who at 27 was one of San Francisco's wealthiest residents and was of Danish and African clescent; and the former homesite of Mary Ellen Pleasant (1820-1904), who blazed hefore Rosa Parks by being the first black person to successfully win a lawsuit against San Francisco railroad companies, because they refused to allow blacks to ride streetcars.

The bus also stopped at the Center for AfriCan and African American Art and Culture (San Francisco) for a tour of its museum and gallery. The center acquires and presents information on the role of black Americans in art and history, and maintains a research library.

All was concluded with a reception at the black-owned Loville's Restaurant on Fisherman's Wharf. The guest speaker, Joseph Rollins, told his mother's story. Charlemae Hill Rollins was a remarkable librarian; her love for books and reading propelled her into the library profession, but her memorable career should never be forgotten. AFAS gives sifa (a Kiswahili word meaning praise) to Charlemae Rollins.-Gladys Smiley Bell. Kent State Iniversity

\section{The Cold War}

ACRL's Anthropology and Sociology Section presented "The Cold War: Social Science Research, Scholarly Communication, and the Development of New Information Resources." Laura Nader, University of California, Berkeley, descrilsed the rigid conformist social mentality that underpinned the militarization of science. The post-World War II growth of universities depended on external funding. Administrations exerted pressure on faculty to pro- 
cure money, and sources outside of academe began to determine the focus of research. The major federal grants were awarded for military-related topics. Area studies programs were originally funded to gather strategic information. The few anthropologists who expressed concern for the use of anthropological work by government agencies were dismissed from prestigious universities. Although the American Anthropological Association delrated the ethical issues involved, action was not forthcoming. Many anthropologists who

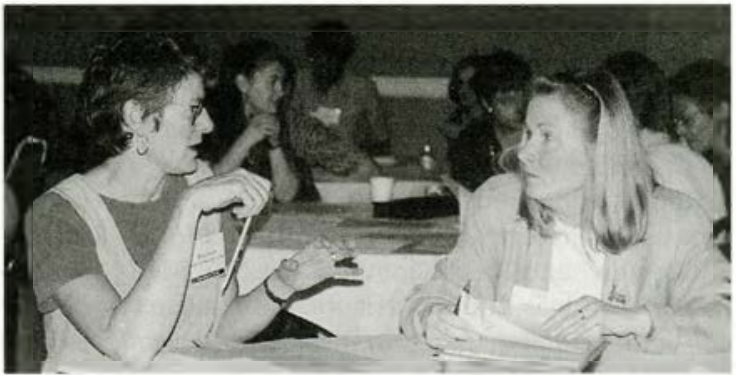

Sallie Harlan and Lenora Berendt participate in one of the workshops offered at the Instruction Section's preconference, “Learning to Teach." Phote credi: M. E. Davis entered the profession from the 1960 s onward are therefore distrustful of their predecessors.

Money from private sources often carried a political agenda also. While the Ford Foundaltion spent more than $\$ 83$ million for social research during the 1950 s, Rebecca Lowen, University of California, San Diego, reported that many Ford officials held direct ties with the U.S. State and Defense Departments. Much Ford money went for research compatible with the interests of the security state (e.g., propaganda, public opinion, etc.)

Military-funded research was a primary force in the development of computer technology. Numerous ways in which the technology reflects its martial origins, including the surveillance capability, were described by peter Lyman, University of Catifornia, Berkeley.
Howard Besser, University of Californial Berkeley, discussed the explosion of published information, the subsequent growth of libraries and the demand for librarians with language and subject expertise, and the emphasis on quantity that began cluring this era. While the traditional sources are eroding, the need for outside funding continues in academe. An awareness of who controls external money is needed-James W. Williams, University of Illinois at Urbana-Champaign

\section{Libraries and the performing arts}

ACRL's Arts Section Dance Librarians Committee and the Thearre Library Association cosponsored the program "From Documentation to Access: Library Collaboration in the Performing Arts.

\section{Order your Annual Conference audiocassettes}

Audiocassettes of selected ACRL programs from the 1997 ALA Annual Conference in San Francisco are now available. Fach program consists of two cassettes and sells for $\$ 24.00$. unless otherwise noted.

The New Generation of Scholars: Do They Really Need Us? Maybe, Maybe Not (ACRL University Libraries Section) Order no. ALA 742

The Cold War: Social Science Research, Scholarly Communication, and the Development of New Information Resources (ACRL Anthropology and Sociology Section) Order no. ALA 744

Freedom of Access: Internet and Intellectual Freedom Issues Briefing for Academic Libraries (ACRL Intellectual
Freedom Committee), 1 cassette, $\$ 12.00$. Order no. ALA 746

The Scientific Researcher: Hardwired for Retrieval or Wedded to Print (ACRI. Science and Technology Section) Order no. ALA 747

Imagining the Learning Library (ACRL President's Program), 3 cassettes, \$36.00. Order no. ALA 748

Audiocassettes for other programs are also available. Call, write, or fax your order or a request for an order form to: Teach'em, 160 E. Illinois St., Ste. 300. Chicago, IL 60611; (312) 467-0424; fax: (312) 467-9271 or (800) 225-3775. You may pay by check (payable to Teachem) or credit card (Visa, MC. AMEX). 
Focusing on Goal 2 of the ACRL Strategic Plan, the four-person panel spotlighted current projects of collaboration between and among performing arts organizations and libraries.

Catherine Johnson, director, Dance Heritage Coalition, addressed "Access to Dance Research Resources Project: A Report on the National Cataloguing and Processing Initiative." Funded by the National Endowment for the Humanities and matching grant monies, the project hegan in 1993 and was completed June 30, 1997 - the day of the program. The project's objectives were to process and catalog primary dance resources in seven repositories, and to create rools to assist in more efficient cataloging and processing in the future. Overall, 73 finding aids were created, 12,500 items were cataloged, 6,600 MARC records were created, and 9,150 authority records were added to LCNAF. The guidelines for cataloging of materials are available for review at www.nypl.org dhc. A total of 56,707 records were prepared for retrieval by LC.

Janet Ross, dance historian and critic, presented "Documenting Leonid Jacobson's Vestris, a Collahoration of SF-PALM and the San Francisco Ballet." Leonid Jacobson (1904-75), a dancer specializing in character and grotesque roles, created Vestris, a series of taxing mime and virtuoso dance vignettes, set to music by Banschikov, for Mikhail Baryshnikov. A young French male dancer recently approached Jacobson's widow, who is currently teaching dance in San Francisco, to coach the work. Ross obtained permission to videotape the coaching process. This documentation of the wife of the choreographer recreating the work of her husband is indispensable to the dance world and will preserve this unique work for generations of scholars and performers.

Margaret Norton, executive director, SFPALM, presented "Improving Video Documentation through a Regional Training Program." In response to the continuing problem of poorly executed video documentation of dance performance, SF-PALM, in collaboration with local dance organizations, obtained funding to train eight videographers for that explicit purpose. During the training process, it became apparent that the choreographers required an expanded understanding of the video documentation process and the videographers needed to understand the unique problems of documenting dance.
Willie Walker (SF-PALM) spoke on "Getting the Right Stuff: Developing a Records Transfer Program for the San Francisco Opera, Ballet and Symphony." Walker addressed the problems of what to save, how to access what is saved, staff issues involved in records preservation decisions, and storage issues. He described a systematic process in which a flowchart first identifies departments that have records that should be preserved, and then what types of files are generated. Each type of file is then analyzed according to categories: how many cubic feet, annual increase, office retention, final disposition, what to destroy initially, space needed to archive in five years, and ultimate space needed to archive. Walker stressed the collaborative process between the archival repository and the organization as well as the collaborative process within the organization required to develop the initial flowchart. The program session was followed by tours to the War Memorial Opera House and the Geary Theatre.-Nancy Stokes, University of Akron

\section{Sex, lies, and electronic reserves}

ACRL'S Copyright Committee presented the program "Sex, Lies and Electronic Reserves: Fair Use or Not." Mary Jackson, Association of Research Libraries, provicled a framework for the session. She identified six overarching issues that need to be considered in electronic reserves. These were 1) content of what is on reserve. both materials created by the instructor and formally published materials; 2 ) technology needed to create the Web site; 3) access and use issues; 4) management issues; 5 ) intellectual property rights; and 6) library practices and policies. She asserted that institutions need to define and develop a library policy on copyright. From within that framework, institutions develop the policies that govern electronic reserves. Among the management issues, four areas were highlighted: who manages the process; who obtains the permissions; how do the paper and electronic reserve systems fit together; and how do course packs and electronic reserves fit together. Dave Davis, Copyright Clearance Center, seconded the notion that institutions need to develop policies governing electronic reserves. Mickie Voges, Chicago-Kent College of Law, Iilinois Institute of Technology, stressed that underlying copyright are the competing interests of the creator and user; copyright's purpose was to further the state of society through an educated populace and at the same time 
assure an incentive or protection for the creator. Don Bosseau, San Diego State University, stated that "electronic reserves wouldn't be interesting without the copyright issue." In his experience, a great deal of effort is cleployed by libraries to obtain permissions. He suggested scientific analysis should be used to test economic models and access for electronic reserves. Practical and workable solutions need to be developed and tried.-Ericka C. Linke, Camegie Mellon University

\section{Freedom of access}

The ACRL Intellectual Freedom Committee sponsored a program called "Freedom of Access.Internet@Intellectual Freedom.Issues Briefing" with speakers Jim Schmidt, San Jose State University, and John Bushman, Rider University. Schmidt gave a thought-provoking and content-packed talk covering some of the important differences between academic and public libraries in the territory of intellectual freedom. Whereas, for example, public libraries usually access the Internet through service providers, academic libraries gain access through their local campus network.

Pointing out that past court cases are not conclusive, Schmidt showed the relatedness between Internet access and the concept of "public forum." Whether a public forum is traditional, limited, or nonpublic could determine the extent and amount of regulation of Internet content.

Another example of technology affecting intellectual freedom is the use of filters to censor types of electronic information. Schmidt surmised that because current filtering systems are vague and overly broad, publicly funded "academic libraries probably can't legally filter."

Schmiclt emphasized that an important step in safeguarding intellectual freedom of electronic information in academic libraries is the active involvement of librarians in university decision-making processes to help establish good local Internet policies.

Bushman's presentation, "IF in the Library Workplace," summarized the results of an informal (but quite interesting) survey on intellectual freedom in the university that he conducted with Mark Rosenzweig for the Progressive Librarians Guild. The results revealed that a large number of people misunderstand important intellectual freedom issues. One surprising finding was a considerable disjunction between how IF is thought to be upheld in academic libraries and the reality.-Charlotte Hess, Indiana University

\section{Using exhibits}

ACRL's Public Relations in Academic Libraries and Exhibits and Displays in College Libraries Discussion Groups cosponsored a program at the new San Francisco Main Library. Laura Lent, exhibitions and programming manager, led the group from the large sixthfloor exhibit space to the interior of the basement to the smaller exhibits work area. Community relations specialist Eleanor Shapiro assisted with the tour.

The exhibit program is so successful at San Francisco Main Library that the library is "inundated with proposals," according to Lent. Proposals are reviewed three times a year. The priorities for the exhibits program are showcasing the library and the local community. In the review process the proposals are judged on how well they meet these priorities and the breadth of the subject matter and the inclusion of local subjects and issues. Most exhibits also involve public programs. Smaller exhibits that can be accommodated in several cases or on one or more bulletin boards are reviewed by the appropriate library department. Lent also gave hints on installing exhibits with a limited budget. She said many exhibits are sponsored by organizations and coalitions from the community and she uses interns to assist with preparation and installation of the exhibits.-Barbara Kile, Rice University

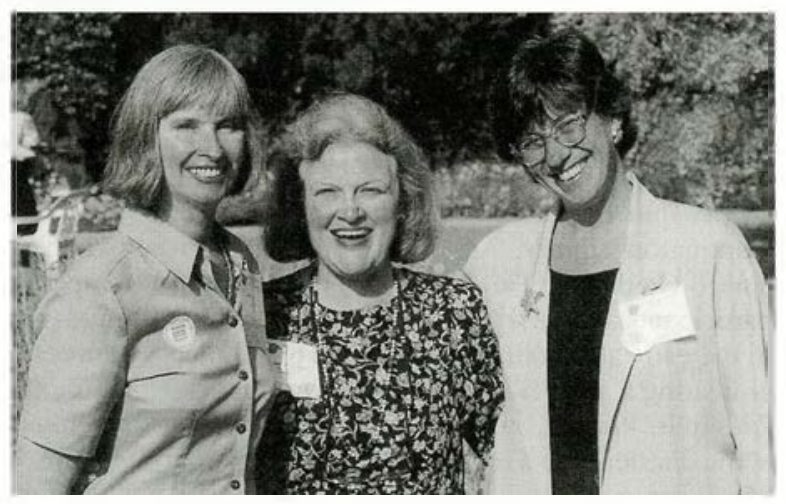

Susan Allen, Judy Harvey Sahak, and Nora Quinlan enjoy a reception on the grounds of the Huntington Library at the RBMS Preconference they planned. Photo credi: M. E. Davis.s 


\section{Rereading the past}

The Rare Books and Manuscripts Section of ACRL held its 38th annual preconference at the Claremont Colleges in Claremont, California, June 24-27, 1997. Entitled "Rereading the Past: New Methodologies and Approaches to the History of the Book," the preconference looked at how research in the history of the book has developed since the 1980 RBMS preconference on the history of the book. "Books and Society in History," while at the same time examining new strategies. In all, 232 people attended, of which 51 were first-time attenclees.

The preconference began with tours, a workshop on letterpress printing, and a successful bookfair organized by the Southern California Chapter of the Antiquarian Booksellers' Association of America. The preconference keynote speaker was Robert A. Gross, College of William and Mary. In his talk, "Communications Revolutions: Writing a History of the Book for the Electronic Age," he congratulated RBMS for first raising many issues at the 1980 preconference that have since become paramount in book studies. He also called the publication from that preconference, "Books and Society in History" (1983), very important in spreading information about the then new field of the history of the book.

The next speaker was Julian Roberts, of the Bodleian Library, Oxford University. In his talk, "From Bibliography to Book History: A British Perspective," Roberts discussed the history of the study of bibliography and surveyed the progress of long-term billiographic projects of imprints, such as the English Short Title Catalogue. On Weclnesday afternoon time was set aside for seminars and a workshop on cataloging. After an outdoor supper, the group attended a concert by soprano Lucy Shelton. Her selections included songs from the repertoire of Ernestine SchumannHeink, whose papers are housed in the Claremont Colleges Honnold Library.

On Thursday, attendees met at the Henry E. Huntington Library, Art Collections, and Botanical Gradens in San Marino. In the morning participants attended short-paper presentations. In the early afternoon attendees had the choice of hearing a slicle talk on the Ellsmere Chaucer Facsimile Project by head book conservator Maria Fredericks, a demonstration of exhibition techniques, or a gallery talk on an exhibit of Mark Catesby's natural history watercolors. The afternoon's plenary speakers were Jeffrey Groves, of Harvey Mudd College, who spoke on how publishing practices of Ticknor \& Fields contributed to the formation of literary canon in the nineteenth century, and Rosalind Remer, of Moravian College, who examined current research into early American publishing enterprises.

On Friday the morning was given over to seminars and to plenary speakers. Steve Ferguson, Princeton University, detailed his survey on merging theory and practice in the history of the book and called for increased eclucation and an award to promote the field. Fllen Dunlap, president of the American Antiquarian Society, detailed how studies in book history have benefited her institution.-Charles Egleston, University of Colorado

\section{Beyond "fair use": issues of intellectual property}

"Intellectual Property in the Digital Library: From the Vatican Library to the Future" was the focus of a presentation by Henry M. Gladney of the IBM Almaden Research Center in San Jose, California, to ACRL's Western European Specialists Section. Gladney described an IBM project to cligitize 100 manuscripts from the Vatican Library as "an early experiment to explore the technical, financial, and practical intellectual property management problems of making illustrated mediaeval manuscripts accessible by the Internet." The total cost of such unclertakings is very high; thus it is unlikely that a large number of the Vatican's collection of 150,000 manuscripts will ever be converted into electronic form.

The need to maintain the intellectual integrity of the images to be disseminated, while at the same time making it difficult to pirate them, prompted the Vatican Library to require the imposition of a highly visible watermark on each digital page. A demonstration of this and other watermarks elicited lively discussion about aesthetic considerations as well as about the likelihood of specialized material being pirated

Gladney noted that posing the question "What is worth protecting?" is crucial when contemplating a digitization project. The answer must take into account such aspects as unique sources, an institution's accessibility and reputation, economic benefits, authors' wishes, reaclers' interests, and also readers' privacy.

The presentation is approximated on Gladney's Web page, available at: http:// almaden.ibm.com/cs/people/gladney/ ala.html.-Nancy Boerner, Indiana UniversityBloomington 


\section{Missing \\ conference data?}

If you are hunting for critical conference proceedings information, look no further than the Index to Scientific or Technical Proceedings ${ }^{\text {'M }}$ on CD-ROM and Index to Social Sciences \& Humanities Proceedings $^{\text {'M }}$ on CD-ROM from ISI ${ }^{\circledR}$.

Updated quarterly, these easy to-search CDs give you every significant detail from important conferences all over the world. It's all cutting-edgc. Why wait to access it?

With rolling, five-year* coverage on single CDs, $I S T P^{\circledR}$ and ISSHP ${ }^{\circledR}$ provide complete information about conferences and newly presented research papers - plus publisher information and a link to

\begin{tabular}{|c|c|}
\hline \multicolumn{2}{|c|}{$\begin{array}{c}\text { ISTP }^{r M} \text { on CD-ROM } \\
\text { science - medicinc - engineering }\end{array}$} \\
\hline First issue & $\begin{array}{l}\text { Oycr } 850,000 \text { papers from } \\
20,000 \text { conference proceedings } \\
\text { published since } 1993 \text {. }\end{array}$ \\
\hline Updates & $\begin{array}{l}\text { Approximately } 45,000 \text { papers } \\
\text { from } 2,000 \text { recently published } \\
\text { conference proceedings. }\end{array}$ \\
\hline \multicolumn{2}{|c|}{$\begin{array}{l}\text { ISSHP } \boldsymbol{P}^{\mathrm{TM}} \text { on CD-ROM } \\
\text { social sciences = humanities }\end{array}$} \\
\hline First issue & $\begin{array}{l}\text { Over } 160,000 \text { papers from } \\
21,000 \text { conference proceedings } \\
\text { published since } 1990 \text {. }\end{array}$ \\
\hline Updates & $\begin{array}{l}\text { Approximately } 6,000 \text { papers } \\
\text { from } 1,100 \text { recently published } \\
\text { conference proceedings. }\end{array}$ \\
\hline
\end{tabular}

*Indcx to Social Scicnces o Humanities Procedings on CD-ROM offers access to 8 years of data and will continuc to cumulate as space allows. ordering full-text conference proceedings through ISI Document Solution ${ }^{\mathrm{SM}}$.

\section{FREE trial CDs available}

Next time you're nosing around for the absolute latest ground-breaking discovery in your field, remem-

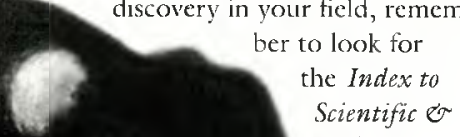
Technical Proceedings and Index to Social Sciences o H Humanities Proceedings on CD ROM. Better yet, call the numbers below for a frec trial CD, or order one from our Web site.

\section{1-800-336-4474} in the U.S., Canada, and Mexico

+44-1895-270016 in Europe, Africa, and the Middle East

\section{5-386-0100}

or contact your subscription agent

To order a free trial from the WWW:

ISTP on CD-ROM www.isinet.com/ prodserv/citation/istpfrm.html ISSHP on CD-ROM www.isinet.com/ prodserv/citation/isshpfrm.html

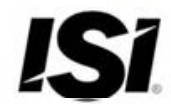

Institute for Scientific Information

Publisher of Current Contents $\left.{ }^{(}\right)$and Science Citation Index ${ }^{(1)}$

United States - Europe - Japan - http://wwwisinet.com 